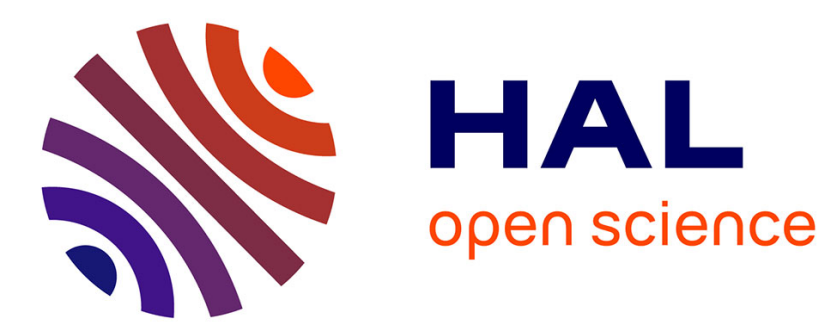

\title{
Visible-light-mediated addition of phenacyl bromides onto cyclopropenes
}

Nitin S Dange, Ashique Hussain Jatoi, Frédéric Robert, Yannick Landais

\section{To cite this version:}

Nitin S Dange, Ashique Hussain Jatoi, Frédéric Robert, Yannick Landais. Visible-light-mediated addition of phenacyl bromides onto cyclopropenes. Organic Letters, 2017, 19 (13), pp.3652-3655. 10.1021/acs.orglett.7b01651 . hal-01737817

\section{HAL Id: hal-01737817 https://hal.science/hal-01737817}

Submitted on 14 May 2018

HAL is a multi-disciplinary open access archive for the deposit and dissemination of scientific research documents, whether they are published or not. The documents may come from teaching and research institutions in France or abroad, or from public or private research centers.
L'archive ouverte pluridisciplinaire $\mathbf{H A L}$, est destinée au dépôt et à la diffusion de documents scientifiques de niveau recherche, publiés ou non, émanant des établissements d'enseignement et de recherche français ou étrangers, des laboratoires publics ou privés. 


\title{
Visible-Light Mediated Addition of Phenacyl Bromides onto Cyclopropenes.
}

\author{
Nitin S. Dange, Ashique Hussain Jatoi, Frédéric Robert, and Yannick Landais*
}

University of Bordeaux, Institute of Molecular Sciences, UMR-CNRS 5255, 351 cours de la libération, 33405 Talence, France.

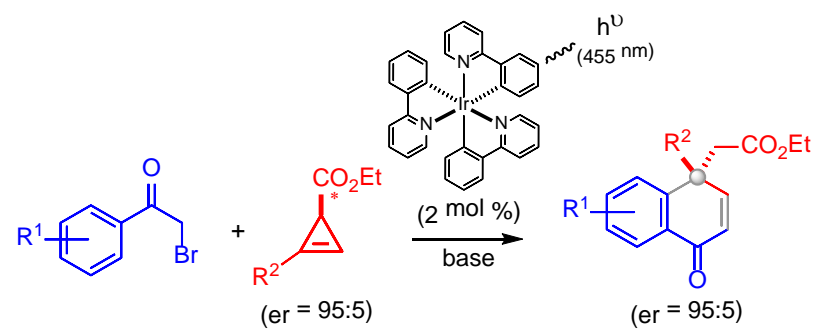

\begin{abstract}
Visible-light promoted addition of $\alpha$-bromoacetophenones onto the cyclopropene $\pi$-system in the presence of the fac$\operatorname{Ir}(\mathrm{ppy})_{3}$ catalyst was shown to afford the corresponding $1(4 \mathrm{H})$-naphthalenones. The syn-carboarylation of the cyclopropene is followed by a cyclopropane ring opening under the basic conditions, allowing the formation of two $\mathrm{C}$-C bonds and the generation of $1(4 \mathrm{H})$-naphthalenones bearing an all-carbon benzylic quaternary stereocenter.
\end{abstract}

Cyclopropenes exhibit remarkable reactivity and behave both as electrophilic and nucleophilic species. ${ }^{1}$ The high acidity of the olefinic protons, due to ring strain, allows their easy deprotonation and further functionalization with electrophiles, while their electrophilicity is revealed during addition of organometallic species, including hydrides, Grignard reagents, organocuprates, zinc and indium reagents. Cyclopropenes may be accessed by a number of methods and are readily available in enantiopure form through metal-catalyzed cyclopropanation of the corresponding alkynes. ${ }^{2}$ These small ring systems thus continue to attract a great deal of interest, but surprisingly, few studies have been reported on their free-radical functionalization. Nakamura et al. first reported cyclopropene radical hydrostannation in $1994 .{ }^{3 a}$ Xanthate- but also bromine atom transfer processes were later described respectively by Saicic, ${ }^{3 \mathrm{~b}} \mathrm{Zard}^{3 \mathrm{c}}$ Miyata, Ueda and co-workers. ${ }^{3 \mathrm{~d}, \mathrm{e}}$ Recent work from our laboratory further enriched this field, with the development of a tinmediated carbocyanation of cyclopropenes. ${ }^{4}$ As a continuation of this work, we report here on the photoredox-catalyzed addition $^{5}$ of $\alpha$-bromoacetophenones II onto cyclopropenes I and the subsequent cyclopropane ring-opening, providing a straightforward access to naphthalenones III bearing a benzylic quaternary stereocenter, which stereochemistry is controlled early during the cyclopropene synthesis (Figure 1). Such a cyclopropene carboarylation should open an access to useful synthons for organic synthesis, the skeleton of which is found in natural products such as labdane terpenoid (-)-kujigamberol ${ }^{6 a}$ or the synthetic analgesic (-)-eptazocine. ${ }^{6 b}$

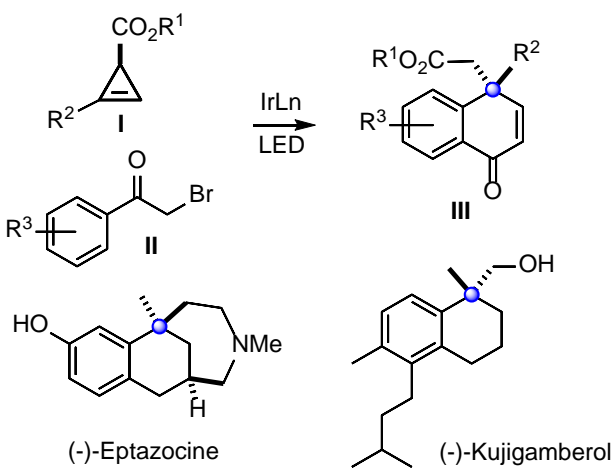

Figure 1. Visible-light mediated addition of phenacyl bromides to cyclopropenes.

In contrast with our recent studies, ${ }^{4,7}$ the carbocyanation of cyclopropene 2a, using $\alpha$-iodoacetophenone 1a in the presence of $p$-TsCN, $\left(\mathrm{Me}_{3} \mathrm{Sn}\right)_{2}$ in benzene at $65^{\circ} \mathrm{C}$ and di-t-butylhyponitrite (DTBHN) as an initiator, did not provide the carbocyanation product, but instead the atom-transfer product $\mathbf{3}$, and unexpectedly the cyclized product $\mathbf{4 a}$ in a 1:1 ratio (Scheme 1). Repeating the experiment without $p$-TsCN led to the same products along with the naphthalenone $\mathbf{5 a}$, which was shown to result from the cyclopropane ring-opening of $\mathbf{4 a}$ under the reaction conditions.

Scheme 1. Addition of $\alpha$-iodoacetophenone 1a to cyclopropene 2a. 


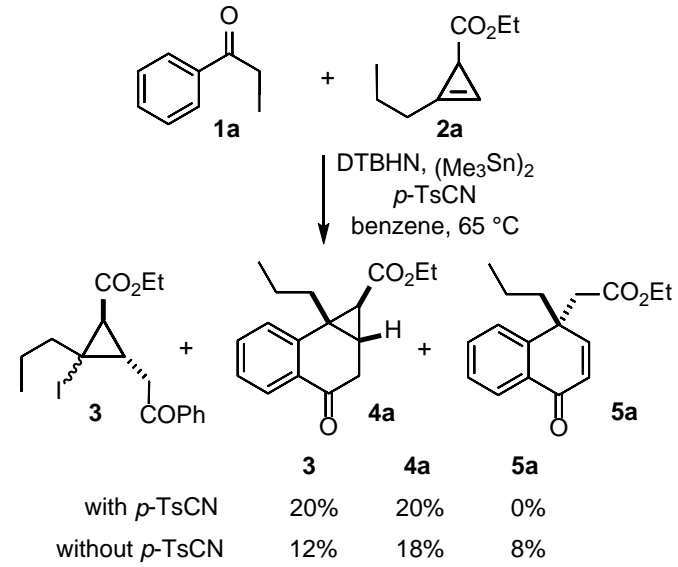

Intramolecular carboarylation of olefins has precedent in the literature but to our knowledge has not been reported with cyclopropenes. $^{8}$ Therefore, considering the synthetic value of compounds such as $\mathbf{5}$ (vide supra), we focused our attention on the development of their one-pot preparation from phenacyl halides and cyclopropenes, relying on an environmentally more benign initiation process than the one used above (Scheme 1). Pioneering studies by Stephenson et al. ${ }^{5 b, 8 a, 9}$ have established that photoredox-catalyzed atom-transfer radical processes using $\alpha$-haloacetophenones were efficiently performed under mild conditions using Ru or Ir catalysts and simple LED irradiation. Optimization of the reaction was thus carried out using several photocatalysts, varying the nature of the base and solvents (Table 1). $\alpha$-Bromoacetophenone $\mathbf{1 b}$ was used instead of $\mathbf{1 a}$ to minimize the atom-transfer reaction. The transformation was first carried out using cheaper $\mathrm{Ru}(\mathrm{bpy})_{3} \mathrm{Cl}_{2}(2 \mathrm{~mol} \%), \mathrm{Et}_{3} \mathrm{~N}$ as a base and $\mathrm{LiBr}^{9}$ as an additive (Table 1 , entry 1 ). This provided the desired naphthalenone $\mathbf{5 a}$, albeit in low yield. Better yield was observed when the reaction was performed in a $\mathrm{DMF}-\mathrm{H}_{2} \mathrm{O}$ mixture (Table 1, entry 2). In the absence of $\mathrm{Et}_{3} \mathrm{~N}$, $\mathbf{4 a}$ was obtained without any trace of $\mathbf{5 a}$, indicating that the base was required for the ring-opening, but not for the photocatalyst turnover (Table 1 , entry 3) (vide infra). fac-Ir(ppy) $)_{3}$ was then tested and displayed lower efficiency under these conditions (Table 1, entry 4). Higher amount of $\mathbf{5 a}$ was however isolated with this catalyst, when $\mathrm{K}_{2} \mathrm{CO}_{3}$ was used as a base (Table 1, entry 5). Interestingly, we noticed that $\mathbf{5 a}$ was decomposed upon long exposure to the LED irradiation. Therefore, the carboarylation process was then performed during $12 \mathrm{~h}$ under irradiation, at which time $\mathbf{4 a}$ was the major product formed. Then the lamp was switch-off and the ring-opening completed by a gentle heating at $60{ }^{\circ} \mathrm{C}$ (Table 1 , entry 6). Slightly higher yields were also obtained at higher concentration (0.2 M) (Table 1, entry 7). An increase of the concentration $(0.4 \mathrm{M})$ or a decrease $(0.05 \mathrm{M})$ led to lower yields. Catalyst loading was also varied, indicating that $2 \mathrm{~mol} \%$ was optimal for this reaction (Table 1, entries 8-9). Finally, the reaction was carried out in the absence of light and photocatalyst, leading in both cases to no product, thus demonstrating the crucial and cooperative role of the Ir complex and visible-light irradiation (vide infra).

The scope of the reaction was then established using optimized conditions (Table 1, entry 7) on a series of acetophenones $\mathbf{1 b}-\mathbf{k}$ and cyclopropenes $\mathbf{2 a - j}$, leading to naphthalenones $\mathbf{5 a - t}$, in moderate yields (Scheme 2). Higher yields are obtained with electron-donating substituents $\left(\mathrm{R}^{2}\right)$ on the phenacyl moiety, illustrating the influence of electronic effects in the process. For instance, when a $p$-CN substituent was present on the acetophenone, the corresponding unsaturated ketone $\mathbf{5 f}$ was not formed, and large amount of p-cyanoacetophenone was recovered instead, indicating that reduction of the bromide was a competing pathway (vide infra). ${ }^{10}$

Table 1. Optimization of the carboarylation of cyclopropene 2a.

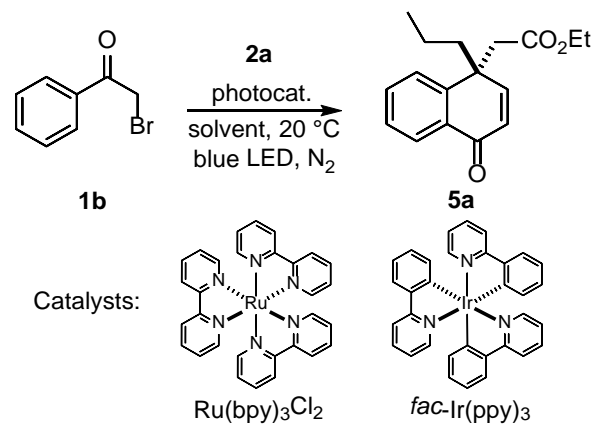

\begin{tabular}{|c|c|c|c|c|c|}
\hline entry & cat. & additive & solvent & Time (h) & yield\% ${ }^{\mathrm{b}}$ \\
\hline 1 & $\mathrm{Ru}^{\mathrm{II}} \mathrm{a}$ & $\mathrm{Et}_{3} \mathrm{~N}, \mathrm{LiBr}$ & DMF & 72 & 10 \\
\hline 2 & $\mathrm{Ru}^{\mathrm{II} \mathrm{a}}$ & $\mathrm{Et}_{3} \mathrm{~N}, \mathrm{LiBr}$ & $\mathrm{DMF}-\mathrm{H}_{2} \mathrm{O}^{\mathrm{c}}$ & 72 & 30 \\
\hline 3 & $\mathrm{Ru}^{\mathrm{II} \text { a }}$ & $\mathrm{LiBr}$ & $\mathrm{DMF}-\mathrm{H}_{2} \mathrm{O}^{\mathrm{c}}$ & 72 & $-d$ \\
\hline 4 & $\mathrm{Ir}^{\mathrm{e}}$ & $\mathrm{Et}_{3} \mathrm{~N}, \mathrm{LiBr}$ & DMF- $\mathrm{H}_{2} \mathrm{O}^{\mathrm{c}}$ & 72 & 15 \\
\hline 5 & $\mathrm{Ir}^{\mathrm{e}}$ & $\mathrm{K}_{2} \mathrm{CO}_{3}$ & DMF & 72 & 34 \\
\hline 6 & $\mathrm{Ir}^{\mathrm{e}}$ & $\mathrm{K}_{2} \mathrm{CO}_{3}, \mathrm{LiBr}$ & DMF & $12^{\mathrm{f}}$ & 40 \\
\hline 7 & $\operatorname{Ir}^{\mathrm{e}}$ & $\mathrm{K}_{2} \mathrm{CO}_{3}, \mathrm{LiBr}$ & $\mathrm{DMF}^{\mathrm{g}}$ & $12^{\mathrm{f}}$ & 44 \\
\hline 8 & $\operatorname{Ir}^{\mathrm{h}}$ & $\mathrm{K}_{2} \mathrm{CO}_{3}, \mathrm{LiBr}$ & $\mathrm{DMF}^{\mathrm{g}}$ & $12^{\mathrm{f}}$ & 22 \\
\hline 9 & $\operatorname{Ir}^{\mathrm{i}}$ & $\mathrm{K}_{2} \mathrm{CO}_{3}, \mathrm{LiBr}$ & $\mathrm{DMF}^{\mathrm{g}}$ & $12^{\mathrm{f}}$ & 39 \\
\hline 10 & $\mathrm{Ir}^{\mathrm{e}}$ & $\mathrm{K}_{2} \mathrm{CO}_{3}, \mathrm{LiBr}$ & $\mathrm{DMF}^{\mathrm{g}}$ & $120^{\mathrm{j}}$ & - \\
\hline 11 & $-k$ & $\mathrm{~K}_{2} \mathrm{CO}_{3}, \mathrm{LiBr}$ & $\mathrm{DMF}^{\mathrm{g}}$ & 120 & - \\
\hline
\end{tabular}

${ }^{\text {a }} \mathrm{Ru}^{\mathrm{II}}$ : $\mathrm{Ru}(\mathrm{bpy}){ }_{3} \mathrm{Cl}_{2}$ (2 mol \%). ${ }^{\mathrm{b}}$ Isolated yields. ${ }^{\mathrm{c}} \mathrm{DMF}-\mathrm{H}_{2} \mathrm{O}=$ $4: 1 .{ }^{\mathrm{d}}$ 4a was isolated (28\%). ${ }^{\mathrm{e}} \mathrm{Ir}$ : $f a c-\operatorname{Ir}(\mathrm{ppy}) 3$ (2 mol \%). ${ }^{\mathrm{f}}$ The reaction mixture was stirred $12 \mathrm{~h}$ under LED irradiation, then heated $24 \mathrm{~h}$ at $60{ }^{\circ} \mathrm{C}$ without irradiation. ${ }^{\mathrm{g}} \mathrm{DMF}(0.2 \mathrm{M}) .{ }^{\mathrm{h}}$ fac-Ir(ppy) 3 (1 mol \%). ${ }^{\mathrm{i}}$ fac-Ir(ppy) $3(4 \mathrm{~mol} \%) .{ }^{\mathrm{j}}$ Without LED irradiation. ${ }^{\mathrm{k}}$ Without photocatalyst.

With $m$-substituted acetophenones, a mixture of regioisomers was isolated (5g-h Scheme 2). The size of the substituents on the cyclopropene ring has a slight influence on the process efficiency, with lower yields observed with cyclic substituents (5op Scheme 2). The reaction was compatible with the presence of silyl ethers, esters and halides as shown by the formation of $\mathbf{5 i}$, $\mathbf{5 k}$ and $\mathbf{5 m}$. Interestingly, naphthalenone $\mathbf{5 q}$ was formed from cyclopropene $2 \mathbf{j}$ having a mesylate substituent $\left(\mathrm{R}^{1}=\right.$ $\left.\left(\mathrm{CH}_{2}\right)_{2} \mathrm{OMs}\right)$, which was readily displaced in situ by $\mathrm{LiBr}$. It is currently not established if the conversion of the mesylate into the bromide occurred before or after the photocatalyzed process. The reaction could also be performed with heteroarenes, leading to the desired compounds $5 \mathbf{r}$-t, albeit with modest yields. Finally, it is worth noticing that, although yields are generally moderate, final naphthalenones $\mathbf{5}$ are easily isolated through silica gel chromatography and obtained in only two synthetic operations from the corresponding commercially available alkynes.

Scheme 2. Scope of the intramolecular carboarylation of cyclopropenes $\mathbf{2 a - j}$. 


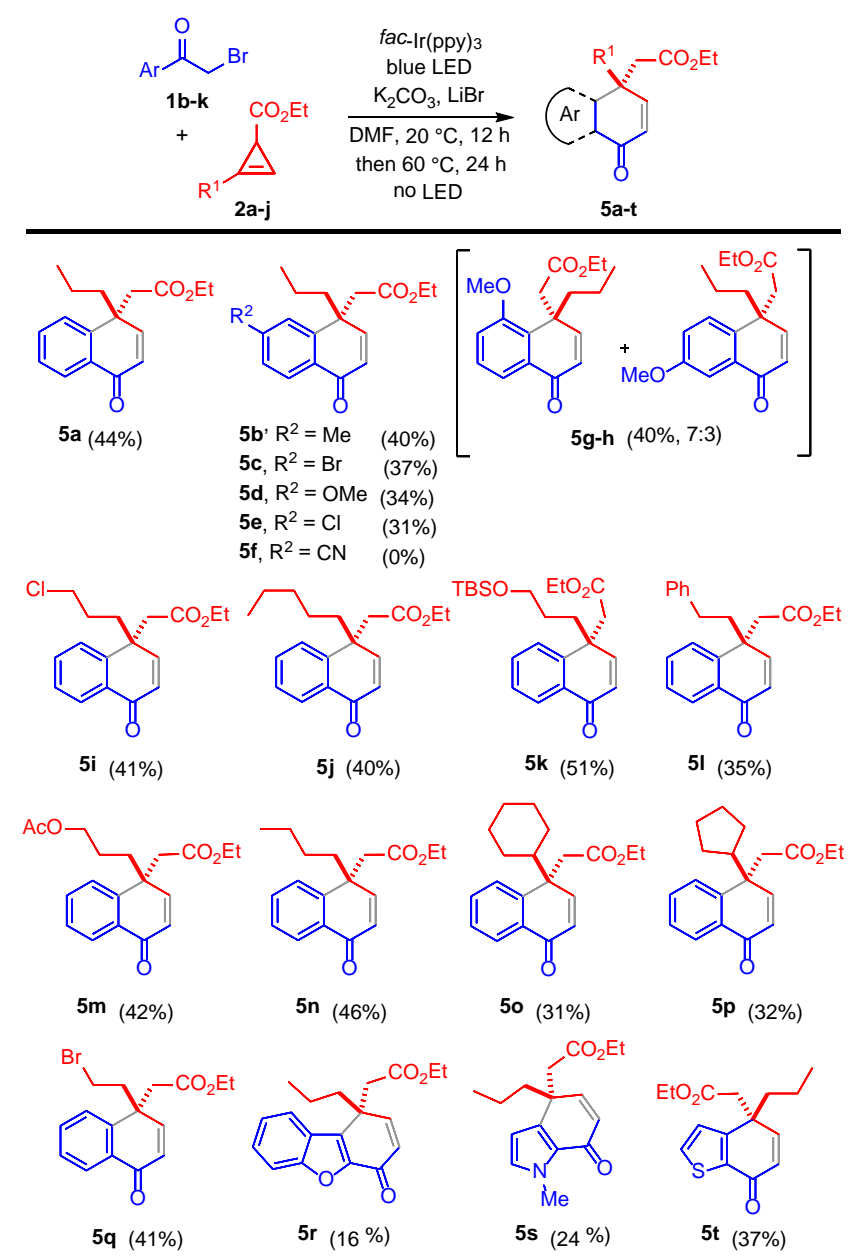

The stereochemical outcome of the carboarylation/cyclopropane ring-opening sequence was studied, applying the reaction to enantioenriched cyclopropene $2 a^{*}$, available through cyclopropanation of pent-1-yne using Corey's chiral rhodium catalyst (Scheme 3). ${ }^{2 \mathrm{C}} \mathbf{5} \mathbf{a}^{*}$ was obtained with the same enantiomeric excess as that of the starting $2 \mathbf{a}^{*}$, indicating that no erosion of the enantioselectivity occurred during the whole sequence.

Scheme 3. I nt ramol ecul ar carboaryl at i on of enant i oenri chedcycl opropene $2 a^{*}$.

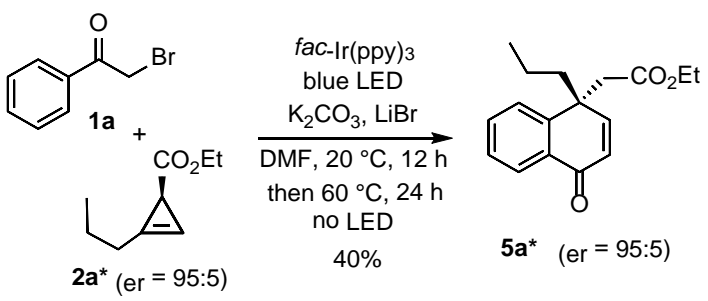

The naphthalenones obtained through this tandem process are useful precursors of polycyclic substrates, as demonstrated with the conversion of $\mathbf{5 m}$ into the corresponding polysubstituted pyrane 6 through a simple treatment under basic conditions (Scheme 4). Carbocycles such as $\mathbf{9}$ may be reached in a straightforward manner starting from mesyl-cyclopropene $\mathbf{7}$ and $\mathbf{1 b}$, the conversion of which, under optimized conditions above led to the bromide $\mathbf{8}$. Conversion of $\mathbf{8}$ into an iodide and then tin-mediated radical cyclization led to $\mathbf{9}$ as a single diastereomer. ${ }^{11}$

Scheme 4. Further elaboration of naphthalenones.<smiles>CCOC(=O)CCC1(CCCOC(=O)OCC)C=CC(=O)c2ccccc21</smiles>

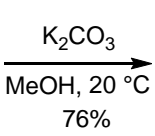
$76 \%$
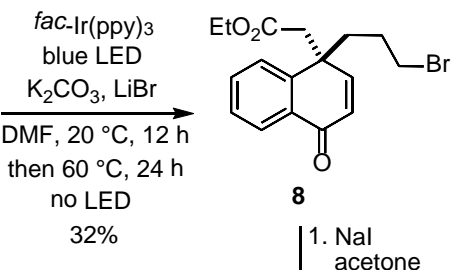
\begin{tabular}{c|l}
$70 \%$ & $\begin{array}{l}\text { 1. } \mathrm{Nal} \\
\text { acetone } \\
\text { (2 steps) }\end{array}$ \\
$\begin{array}{l}\text { 2. } \mathrm{Bu}_{3} \mathrm{SnH}, \text { AIBN } \\
\text { benzene } \\
80^{\circ} \mathrm{C}, 12 \mathrm{~h}\end{array}$
\end{tabular}<smiles>CCOC(=O)C[C@]12CCC[C@H]1CC(=O)c1ccccc12</smiles>

A mechanistic pathway was finally proposed to rationalize the course of the tandem process (Figure 2). This would involve, as a first step, a single electron transfer from the photocatalyst excited state $\left(f a c-\operatorname{Ir}(\mathrm{ppy})_{3}{ }^{*}\right)$ to the bromide $\mathbf{1 b}$, affording the $\alpha$ phenacyl radical $i$. fac-Ir(ppy) $)_{3}$ exhibits a sufficiently strong reduction potential $\left(\mathrm{E}_{1 / 2}=-1.73 \mathrm{~V} \text { vs } \mathrm{SCE}\right)^{12 \mathrm{a}}$ to convert $\mathbf{1 b}(-$ $0.49 \mathrm{~V}$ vs SCE) ${ }^{12 \mathrm{~b}}$ into a radical-anion and then to $\boldsymbol{i}^{8 \mathrm{a}, \mathrm{b}}$ The generation of the latter was shown by a radical trapping experiment using TEMPO, which led to the formation of $\mathbf{1 0}$. When the same reaction was performed in the presence of cyclopropene $\mathbf{2 a}, \mathbf{1 0}$ was also formed in $50 \%$ yield. $\boldsymbol{i}$ then adds onto the cyclopropene $\mathbf{2}$ to generate the highly reactive cyclopropyl radical $\boldsymbol{i i},{ }^{13}$ which reacts intramolecularly with the arene moiety to afford the cyclohexadienyl radical iii. When using $\alpha$-iodoacetophenone, iodine atom transfer reaction was shown to compete with the intramolecular reaction (Scheme 1). ${ }^{14}$ The homolytic aromatic substitution (HAS) is then completed through the oxidation of iii into iv, which rearomatizes through deprotonation under the basic conditions, to provide cyclopropane 4. Oxidation of iii into $i v$ is favored ${ }^{15}$ due to the high oxidative power of $\operatorname{Ir}^{+}\left(E_{1 / 2}=\right.$ $+0.77 \mathrm{~V}$ vs SCE), ${ }^{5 \mathrm{a}}$ which returns the iridium catalyst in its ground state. Single electron transfer from iii to $\mathbf{1}$ to generate $\boldsymbol{i}$ and $\boldsymbol{i} \boldsymbol{v}$ is another option to sustain the radical chain (but not the Ir catalytic cycle) ${ }^{16} \mathbf{4}$ is finally converted in situ into naphthalenone 5 through deprotonation $\alpha$ - to the ketone, followed by cyclopropane-ring opening. ${ }^{4}$ This mechanism is consistent with the stereochemistry of $\mathbf{4 a}$, resulting from an addition of radical $\boldsymbol{i}$ anti relative to the ester group as in $\mathbf{i i},{ }^{4}$ followed by the reaction of the cyclopropyl radical onto the arene from the same face. This syn addition (imposed by geometrical constrains) of the phenacyl radical across the cyclopropene $\pi$-system thus ensures a complete transfer of chirality from the stereocenter $\mathrm{C} 1$ to the newly created stereocenters at $\mathrm{C} 2$ and C3. Chirality at C3 is thus preserved upon base-promoted cyclopropane ring opening as shown in Scheme 3. 


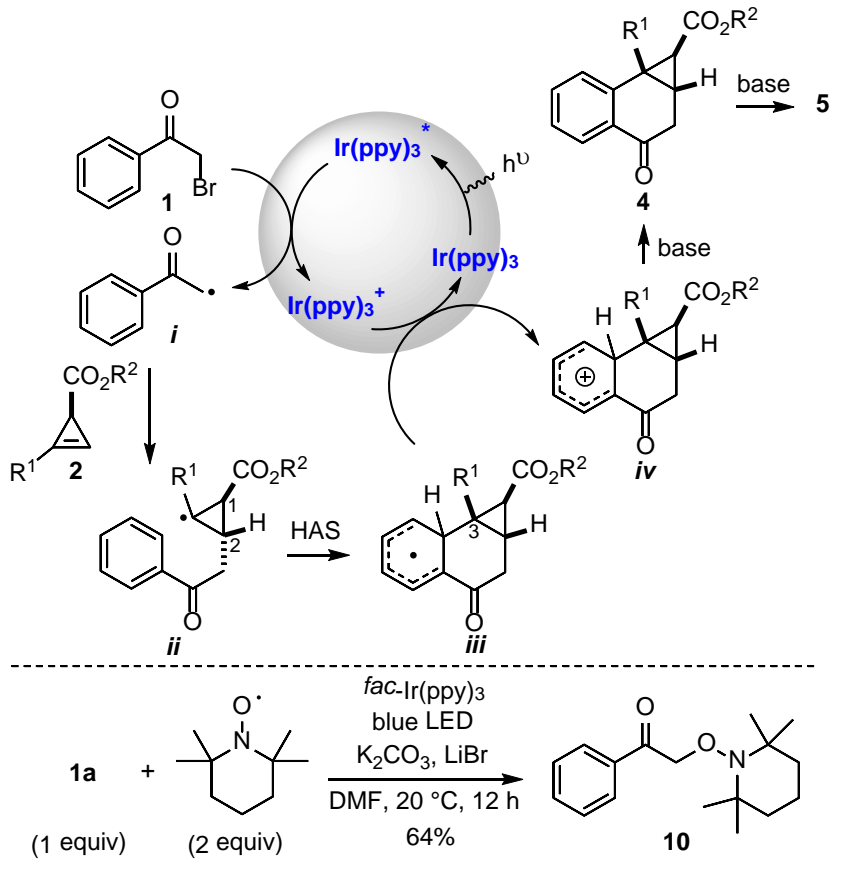

Figure 2. Proposed mechanism for the radical addition of phenacyl bromides to cyclopropenes.

In summary, we reported a straightforward synthesis of substituted 1(4)-naphthalenones, bearing a benzylic quaternary stereocenter, through a one pot visible light-mediated addition of $\alpha$ bromoacetophenones to cyclopropenes. Although the overall yield is moderate, this methodology offers an access to useful intermediates and constitutes a new way to generate synthons with quaternary stereocenter, still a challenging task in organic synthesis. $^{4,17}$ This methodology uses readily available enantioenriched cyclopropenes as starting material, the stereospecific syn carboarylation of the cyclopropene $\pi$-system allowing the formation of two new C-C bonds and ensuring a perfect control of the stereochemistry of the quaternary stereocenter. Application of this methodology to the enantioselective synthesis of bioactive targets such as (-)-eptazocine is now underway and will be reported in due course.

\section{AUTHOR INFORMATION}

\section{Corresponding Author}

*y.landais@ism.u-bordeaux1.fr

\section{ACKNOWLEDGMENT}

ND thanks EU for a postdoctoral grant through H2020 Marie-Curie IF program ( $\left.{ }^{\circ} 655527\right)$. AH thank the Shaheed Benazir Bhutto University for a PhD grant. The University of Bordeaux and CNRS are gratefully acknowledged for financial support.

\section{REFERENCES}

(a) Rubin, M.; Rubina, M.; Gevorgyan, V. Chem. Rev. 2007, 107, 3117. (b) Zhu, Z.-B.; Wei, Y.; Shi, M. Chem. Soc. Rev. 2011, 40, 5534. (c) Archambeau, A.; Miege, F.; Meyer, C.; Cossy, J. Acc. Chem. Res. 2015, 48, 1021. (d) Vicente, R. Synthesis 2016, 48, 2343. (e) Marek, I.; Simaan, S.; Masarwa, A. Angew. Chem., Int. Ed. 2008, 47, 1982. (f) Raha Roy, S.; Didier, D.; Kleiner, A.; Marek, I. Chem. Sci. 2016, 7 , 5989. (g) Ravasco, J. M. J. M.; Monteiro, C. M.; Trindade, A. F. Org.
Chem. Front. 2017, 4, 1167. (h) Edwards, A.; Rubina, M.; Rubin, M. Curr. Org. Chem. 2016, 20, 1862. (i) Archambeau, A.; Miege, F.; Cossy, J.; Meyer, C. in Chemistry of Organogold Compounds, Ed. Rappoport, Z.; Liebman, J. F.; Marek, I. 2014, 2, 631. (j) Song, C.; Wang, J.; Xu, Z. Org. Biomol. Chem. 2014, 12, 5802. (k) Baird, M. S. Chem. Rev. 2003, 103, 1271.

(2) (a) Protopopova, M. N.; Doyle, M. P.; Müller, P.; Ene, D. J. Am. Chem. Soc. 1992, 114, 2755. (b) Doyle, M. P.; Ene, D. G.; Peterson, C. S.; Lynch, V. Angew. Chem. Int. Ed. 1999, 38, 700. (c) Lou, Y.; Horikawa, M.; Kloster, R. A.; Hawryluk, N. A.; Corey, E. J. J. Am. Chem. Soc. 2004, 126, 8916. (d) Goto, T.; Takeda, K.; Shimada, N.; Nambu, H.; Anada, M.; Shiro, M.; Ando, K.; Hashimoto, S.-I. Angew. Chem. Int. Ed. 2011, 50, 6803. (e) Boruta, D. T.; Dmitrenko, O.; Yap, G. P. A.; Fox, J. M. Chem. Sci. 2012, 3, 1589. (f) Cui, X.; Xu, X.; Lu, H.; Zhu, S.; Wojtas, L.; Zhang, X. P. J. Am. Chem. Soc. 2011, 133, 3304.

(3) (a) Yamago, S.; Ejiri, S.; Nakamura, E. Chem. Lett. 1994, 1889. (b) Ferjancic, Z.; Cekovic, Z.; Saicic, R. N. Tetrahedron Lett. 2000, 41 2979. (c) Legrand, N.; Quiclet-Sire, B.; Zard, S. Z. Tetrahedron Lett. 2000, 41, 9815. (d) Ueda, M.; Doi, N.; Miyagawa, H.; Sugita, S.; Takeda, N.; Shinada, T.; Miyata, O. Chem. Commun. 2015, 51, 4204. (e) Doi, N.; Takeda, N.; Miyata, O.; Ueda, M. J. Org. Chem. 2016, 81, 7855.

(4) Dange, N. S.; Robert, F.; Landais, Y. Org. Lett. 2016, 18, 6156.

(5) Selected reviews on visible-light photoredox catalysis: (a) Prier, C. K.; Rankic, D. A.; MacMillan, D. W. C. Chem. Rev. 2013, 113, 5322. (b) Narayanam, J. M. R.; Stephenson, C. R. J. Chem. Soc. Rev. 2011, 40, 102. (c) Romero, N. A.; Nicewicz, D. A. Chem. Rev. 2016, 116, 1007. (d) Shi, L.; Xia, W. Chem. Soc. Rev. 2012, 41, 7687. (e) Hopkinson, M. N.; Sahoo, B.; Li, J.-L.; Glorius, F. Chem. Eur. J. 2014, 20, 3874. (f) Ju, X.; Liang, Y.; Jia, P.; Li W.; Yu, W. Org. Biomol. Chem., 2012, 10, 498.

(6) (a) Ye, Y. Q.; Koshino, H.; Hashizume, D.; Minamikawa, Y.; Kimura, K.-i.; Takahashi, S. Bioorg. Med. Chem. Lett. 2012, 22, 4259. (b) Lim, H. J. L.; Rajanbabu, T. V. Org. Lett. 2011, 13, 6596 and references cited therein.

(7) Hassan, H.; Pirenne, V.; Wissing, M.; Chahinaz, K.; Hussain, A.; Robert, F.; Landais Y. Chem. Eur. J. 2017, 23, 4651.

(8) (a) Tucker, J. W.; Narayanam, J. M. R.; Krabbe, S. W.; Stephenson, C. R. J. Org. Lett. 2010, 15, 4884. (b) Jiang, H.; Cheng, Y.; Zhang, Y.; Yu, S. Org. Lett. 2013, 12, 368. (c) Fu, W.; Zhu, M.; Zou, G.; Xu, C.; Wang, Z.; Ji, B. J. Org. Chem. 2015, 80, 4766. (d) Adaouma, C.; Keyrouz, R.; Pilet, G.; Monnereau, C.; Gueyrard, D.; Noël, T.; Médebielle, M. Chem. Commun. 2017, 53, 5653. (e) Cheng, J.; Deng, X.; Wang, G.; Li, Y.; Cheng, X.; Li, G. Org. Lett. 2016, 18, 453. (f) Liard, A.; Quiclet-Sire, B.; Saicic R. N.; Zard S. Z. Tetrahedron Lett. 1997, 38, 1759. (g) Quiclet-Sire, B.; Zard, S. Z. Top Curr Chem. 2006, 264, 201 and references cited therein.

(9) Wallentin, C.-J.; Nguyen, J. D.; Finkbeiner, P.; Stephenson, C. R. J. J. Am. Chem. Soc., 2012, 134, 8875.

(10) Fukuzumi, S.; Mochizuki, S.; Tanaka, T. J. Phys. Chem. 1990, 94, 722

(11) Clive, D. L. J.; Sunasee, R.; Chen, Z. Org. Biomol. Chem. 2008, 6, 2434.

(12) (a) Shih, H.-W.; Vander Wal, M. N.; Grange R. L.; MacMillan, D. W. C. J. Am. Chem. Soc. 2010, 132, 13600. (b) Tanner, D. D.; Singh, H. K. J. Org. Chem. 1986, 51, 5182.

(13) Walborsky, H. M. Tetrahedron 1981, 37, 1625.

(14) Johnston, L. J.; Scaiano, J. C.; Ingold, K. U. J. Am. Chem. Soc. 1984, 106, 4877.

(15) Redox potential for cyclohexadienyl radical is $\mathrm{E}=-0.1 \mathrm{~V}$ (vs SCE), see: Bhatia, K.; Schuler, R. H. J. Phys. Chem. 1974, 78, 2335.

(16) Studer, A.; Curran, D. P. Angew. Chem. Int. Ed. 2016, 55, 58.

(17) (a) Quasdorf, K. W.; Overman, L. E. Nature, 2014, 516, 181. (b) Hong, A. Y.; Stoltz, B. M. Eur. J. Org. Chem. 2013, 2745. (c) Murphy, J. J.; Bastida, D.; Paria, S.; Fagnoni, M.; Melchiorre P. Nature 2016, 532, 218. For reports on the use of cyclopropenes to set up all-carbon quaternary stereocenters, see: (d) Zhang, F.-G.; Eppe, G.; Marek, I. Angew. Chem. Int. Ed. 2016, 55, 714. (e) Müller, D. S.; Marek, I. Chem. Soc. Rev. 2016, 46, 4552. 